\title{
KETERKAITAN KUALITAS RUANG DENGAN ADAPTASI SPASIAL DI ASRAMA SEKOLAH LUAR BIASA
}

\author{
Eko Widodo ${ }^{1 *}$, Syam R. Marcillia ${ }^{2}$ \\ *) Corresponding author email : eko.widodo@mail.ugm.ac.id \\ Departemen Teknik Arsitektur dan Perencanaan, Fakultas Teknik, Universitas Gadjah Mada \\ Jalan Grafika No.2, Yogyakarta - Indonesia
}

\begin{tabular}{l}
\hline Article info \\
MODUL vol 20 no 1, issues period 2020 \\
\hline Doi $\quad: 10.14710 /$ mdl.20.1.2020.66-74 \\
Received $: 11$ April 2020 \\
Revised $: 29$ April 2020 \\
Accepted $: 7$ Mei 2020
\end{tabular}

\section{Abstrak}

Kualitas lingkungan merupakan aspek penting yang memiliki kontribusi bagi kebutuhan akomodasi yang mempengaruhi kualitas hidup seseorang, termasuk diantaranya kesehatan mental dan fisik. Belum tersedianya standar baku perencanaan asrama sekolah berimplikasi pada variasi setting fisik yang beragam, sehingga menarik untuk dikaji terkait beberapa aspek terkait kualitas lingkungannya. Studi ini dilakukan di tiga asrama sekolah luar biasa yang memiliki setting fisik berbeda dengan fokus amatan adalah anak tunagrahita. Metode penelitian dilakukan dengan menerapkan konsep Habitability Threshold yang terdiri dari psychological, functional, dan physical comfort pada kuesioner untuk memperoleh data persepsi dan penilaian kualitas asrama SLB dari anak tunagrahita. Selanjutnya data tersebut akan direkonsiliasikan dengan pemanfaatan ruang dan adaptasi spasial di ruang-ruang terukur (privat, semipublik, dan publik) berdasarkan pemetaan perilaku place centered mapping. Hasil studi menunjukkan, bahwa kualitas ruang yang dimiliki oleh ketiga lokasi studi terbilang baik. Hal ini dapat dilihat dari angka penilaian yang diperoleh, serta besaran prosentase pemanfaatan ruang yang lebih tinggi daripada adaptasi spasial yang dilakukan anak tunagrahita. Walaupun demikian, beberapa aspek masih menjadi perhatian penting, antara lain voice control, luasan. dan temperature.

Kata Kunci: Kualitas Lingkungan; Asrama SLB; Tunagrahita; Pemanfaatan; Adaptasi Spasial

Eko Widodo, Syam R. Marcillia

\section{Pendahuluan}

Asrama merupakan salah satu fasilitas sekolah yang umumnya dikembangkan di sekitar area sekolah, yang selanjutnya oleh TS 11498 (1994) didefinisikan sebagai bangunan dimana kebutuhan siswa seperti, tidur, istirahat, belajar, kegiatan sosial, dan makanan terpenuhi (Yildirim \& Uzun, 2010).

Merujuk pada PSMA (2018) asrama Sekolah Luar Biasa (SLB) merupakan jenis Day Boarding, dimana hanya sebagian kecil peserta didik yang tinggal di dalamnya. Hal tersebut umumnya dikarenakan jarak yang jauh atau kebutuhan tertentu dalam konteks pilihan pembelajaran, misalnya ada peserta didik yang menghendaki mendapatkan layanan pendidikan tertentu. Selain itu, asrama SLB termasuk kategori Special-Needs Boarding School yang hadir untuk memberikan kemudahan layanan dan membangun sosialisasi di antara anak-anak berkebutuhan khusus (ABK) tersebut. Merujuk pada Menhumkam (2016) pengertian ABK atau Penyandang disabilitas adalah:

"Setiap orang yang mengalami keterbatasan fisik, intelektual, mental, dan/atau sensorik dalam jangka waktu lama yang dalam berinteraksi dengan lingkungan dapat mengalami hambatan dan kesulitan untuk berpartisipasi secara penuh dan efektif dengan warga negara lainnya berdasarkan kesamaan hak".

Berdasarkan pernyataan di atas, pada dasarnya sekolah berasrama merupakan salah satu alternatif model pendidikan yang sedang dikembangkan di Indonesia saat ini untuk memberikan kemudahan bagi peserta didik, dalam kasus ini ABK yang bersekolah di SLB. Namun melihat kondisi yang ada saat ini, perhatian terhadap sekolah berasrama tersebut belum optimal (PSMA, 2018).

Salah satu permasalahan asrama SLB adalah belum adanya standar perencanaan asrama siswa, sekalipun terdapat Permendiknas Nomor 33 Tahun 2008 tentang Standar Sarana dan Prasarana SLB, namun di 
dalamnya tidak mengatur perihal tersebut di atas. Menurut Wulandari (2016) di beberapa negara, asrama dirancang dan dibangun berdasarkan standar-standar yang telah disesuaikan dengan jenjang pendidikan penghuninya. Sebagai contoh, Unit Perancang Ekonomi di Malaysia telah mengeluarkan Garis Panduan dan Peraturan bagi Perancangan Bangunan, termasuk di dalamnya jenis asrama, standar, dan kebutuhan ruang. Selain itu, panduan perancangan tersebut disusun dengan memperhatikan berbagai faktor, seperti kebersihan, keamanan, standar dimensi ruang, kelengkapan fasilitas, dan kebutuhan ruang sosialisasi bagi penghuni asrama. Melihat kasus pesantren, pada umumnya tidak dirancang dengan baik dan menjadikan desain asrama hanya sebagai bentuk representasi dari lembaga yang bersangkutan (Yusuf, Hayati, \& Faqih, 2018a), hal ini hampir sama dengan kondisi yang ditemukan di SLB. Padahal, menurut Kocaman et al., (2017) akomodasi adalah salah satu kebutuhan paling penting untuk menyediakan dan mempertahankan perasaan aman. Bangunan asrama harus dievaluasi secara hati-hati dari sudut pandang kebutuhan, tata ruang, dan kondisi kenyamanan. Ketika bangunan asrama ini tidak dapat memenuhi kebutuhan penghuni, maka bangunan tersebut akan cenderung menjadi tempat tidur daripada asrama.

Kamar tidur asrama adalah tempat paling penting untuk kegiatan sehari-hari peserta didik (Azzahro, 2017 dalam Yusuf et al., 2018a), sehingga kajian tentang tingkat keterkaitan antara hubungan desain ruang dan fasilitas asrama dengan perilaku penghuni perlu dilakukan, dimana hasil kajian tersebut dapat digunakan untuk menyusun panduan desain asrama yang sesuai dengan kebutuhan dan karakter penghuni secara umum (R. Wulandari, 2016). Selain itu, desain asrama dengan menggunakan preferensi dan adaptasi sangat penting. Hal ini merujuk pada hasil studi yang dilakukan oleh Mu'in, et al., (2006) dalam Yusuf dkk., (2018b), bahwa adaptasi siswa umumnya terjadi karena kurangnya infrastruktur di dalam asrama.

Selain itu, masih diperlukan fasilitas lain di dalam asrama selain kamar, hal ini mengingat aktivitas harian yang tidak hanya tidur, tetapi juga makan, minum, belajar, aktivitas mencuci dan memasak, kegiatan higienis pribadi, serta bersosialisasi (Chiara \& Callender, 1983). Apabila ditinjau kembali, terdapat keterkaitan antara setting lingkungan dengan pola perilaku penghuni asrama. Hal ini sebagai bentuk respon individu dan kelompok terhadap kondisi lingkungannya (R. Wulandari, 2016).

Beberapa penelitian asrama siswa yang sudah dilakukan lebih banyak mengkaji studi kasus pondok pesantren dan asrama mahasiswa. Aspek pembahasan juga lebih banyak ke edukasi, psikologi, dan sosial. Pada umumnya kajian tentang desain asrama atau arsitektur asrama tidak berdiri sendiri, seringkali berkaitan dengan aspek psikologi, isu hubungan atau interaksi sosial, budaya dan agama, hingga kepadatan ruang.

Melihat celah tersebut, penelitian terkait asrama SLB penting untuk dilakukan. Adapun topik pembahasan adalah keterkaitan kualitas ruang dengan adaptasi spasial ABK dalam melakukan aktivitas harian (living activity) di asrama SLB. Hal ini mengingat, bahwa keterbatasan ABK juga perlu mendapatkan perhatian dalam memperoleh fasilitas yang tidak hanya berorientasi pada kenyamanan akomodasi, tetapi bagaimana ruang-ruang di dalamnya bisa memenuhi aspek kualitas kesehatan fisik dan psikologinya

\section{Metode Penelitian}

Penelitian ini dilakukan pada bulan Januari s.d. Maret 2020 di tiga asrama SLB berbeda yang berada di Yogyakarta dengan fokus amatan anak tunagrahita (selanjutnya akan disebut ATG). Secara umum definisi tunagrahita adalah anak berkebutuhan khusus yang memiliki keterbelakangan dalam intelegensi, fisik, emosional, dan sosial (Desiningrum, 2016). Definisi lain yang dirumuskan oleh Grossman (1983) dalam Wardani dkk, (2007) dan telah menjadi rujukan utama, serta secara resmi digunakan oleh AAMD (American Association on Mental Deficiency) sebagai berikut:

"Mental retardation refers to significantly subaverage general intellectual functioning resulting in or adaptive behavior and manifested during the developmental period".

Pengambilan data dilakukan melalui dua cara, yaitu penilaian kualitas lingkungan melalui kuesioner skala likert dengan pertimbangan bahwa metode ini lebih mudah diimplementasikan bagi ATG. Selanjutnya, peneliti melibatkan ATG yang memiliki kemampuan komunikatif yang baik untuk memberikan jawaban kuesioner dengan dibantu oleh Guru pendamping atau Pembina asrama agar bisa memberikan jawaban yang sesuai dengan konteks pertanyaan yang diajukan. Daftar pertanyaan merupakan turunan dari konsep Habitability Threshold (Vischer, 1989 dalam Vischer \& Wifi, 2017), meliputi aspek pshycological, functional, dan physical comfort. Penilaian dilakukan pada tiga ruang terukur, meliputi ruang privat (kamar), semipublik (ruang tengah dan ruang televisi), serta publik (teras).

Tabel 1. Kuesioner Penelitian (Konsep Habitability Threshold Vischer \& Wifi, 2017 dimodifikasi oleh Penulis, 2020)

\begin{tabular}{ll}
\hline \multicolumn{1}{c}{ Aspects } & \multicolumn{2}{c}{ Qualities being assessed } \\
\hline & Suasana di dalam (ruang terukur) \\
Psychological & mendukung aktivitas saya (jenis \\
Comfort & aktivitas privat/semipublik/publik)* \\
& tanpa ada gangguan suara dari teman \\
\hline
\end{tabular}




\begin{tabular}{|c|c|}
\hline Aspects & Qualities being assessed \\
\hline & sekamar. \\
\hline & $\begin{array}{l}\text { - Suasana di dalam (ruang terukur) } \\
\text { mendukung aktivitas saya (jenis } \\
\text { aktivitas privat/semipublik/publik) } \\
\text { tanpa takut dilihat oleh orang lain. }\end{array}$ \\
\hline & $\begin{array}{l}\text { - Suasana di dalam (ruang terukur) } \\
\text { mendukung aktivitas saya (jenis } \\
\text { aktivitas privat/semipublik/publik) } \\
\text { dengan leluasa/ bebas bergerak. }\end{array}$ \\
\hline \multirow{8}{*}{$\begin{array}{l}\text { Functional } \\
\text { Comfort }\end{array}$} & $\begin{array}{l}\text { - Suhu di dalam (ruang terukur) } \\
\text { mendukung aktivitas saya (jenis } \\
\text { aktivitas privat/semipublik/publik) } \\
\text { dengan nyaman. }\end{array}$ \\
\hline & $\begin{array}{l}\text { - Pencahayaan di dalam (ruang terukur) } \\
\text { mendukung aktivitas saya (jenis } \\
\text { aktivitas privat/semipublik/publik) } \\
\text { dengan nyaman. }\end{array}$ \\
\hline & 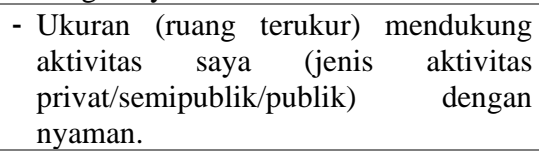 \\
\hline & $\begin{array}{ll}\text { - Perabot di dalam (ruang terukur) } \\
\text { mendukung } & \text { aktivitas saya (jenis } \\
\text { aktivitas } & \text { privat/semipublik/publik) } \\
\text { dengan baik. } & \end{array}$ \\
\hline & 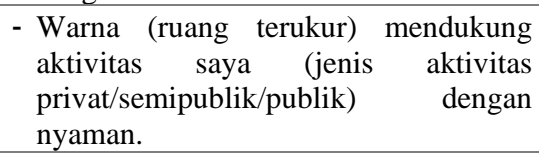 \\
\hline & $\begin{array}{l}\text { - Suasana di dalam (ruang terukur) tidak } \\
\text { berisik, sehingga mendukung (jenis } \\
\text { aktivitas privat/semipublik/publik) } \\
\text { dengan nyaman. }\end{array}$ \\
\hline & $\begin{array}{l}\text { - Kondisi di dalam (ruang terukur) } \\
\text { bersih, sehingga mendukung (jenis } \\
\text { aktivitas privat/semipublik/publik) } \\
\text { dengan nyaman. }\end{array}$ \\
\hline & 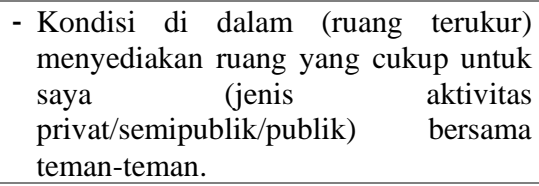 \\
\hline $\begin{array}{l}\text { Physical } \\
\text { Comfort }\end{array}$ & $\begin{array}{l}\text { - Suasana di dalam (ruang terukur) } \\
\text { aman, sehingga sehingga mendukung } \\
\text { (jenis } \\
\text { privat/semipublik/publik) } \\
\text { nyaman. }\end{array}$ \\
\hline
\end{tabular}

*Jenis aktivitas: privat (tidur); semipublik (menonton televisi); publik (bersosialisasi).

Adapun kuesioner likert yang digunakan adalah model modifikasi empat skala penilaian dengan skor yang diberikan pada masing-masing pertanyaan, dikategorikan menjadi: 4 (Sangat Setuju), 3 (Setuju), 2 (Tidak Setuju), dan 1 (Sangat Tidak setuju). Untuk skala "Netral atau Ragu-ragu" sengaja dihilangkan, mengingat keterbatasan berbahasa yang dimiliki oleh anak tunagrahita. Hal ini dilakukan untuk menghindari jawaban multi interpretable yang tidak diharapkan dan berpeluang menghilangkan banyak data penelitian, yang oleh Hadi (1991) alasan modifikasi tersebut termasuk ke dalam kategori undeciden.

Kedua, pendataan melalui pemetaan perilaku place centered mapping (Sommer \& Sommer, 1980) dilakukan untuk memverifikasi data terkait pemanfaatan ruang dan adaptasi spasial yang dilakukan anak tunagrahita pada aktivitas harian yang dilakukan di dalam asrama SLB. Pemetaan perilaku dilakukan selama tujuh hari di masing-masing lokasi dengan rentang waktu antara pukul 06.00 s.d. 21.00 Wib. Selanjutnya, data tersebut akan digunakan untuk mengkonfirmasi hasil penilaian yang diberikan anak tunagrahita terhadap ruang-ruang terukur.

\section{Lokasi Amatan}

Penelitian ini dilakukan di tiga asrama SLB dengan setting fisik yang berbeda, yaitu SLB Negeri 1 Kulon Progo, SLB C Wiyata Dharma 2, dan SLB PGRI Minggir. Fokus penelitian dilakukan pada ruang privat (kamar), semipublik (ruang tengah dan ruang televisi), serta publik (teras). Hal ini dilakukan untuk mendapatkan gambaran terkait kualitas ruang yang diperoleh ATG di masing-masing area tesebut, mengingat pada ketiga area tersebut merupakan dominasi aktivitas harian ATG banyak dilakukan. Berikut kondisi eksisting tiga asrama SLB tersebut:
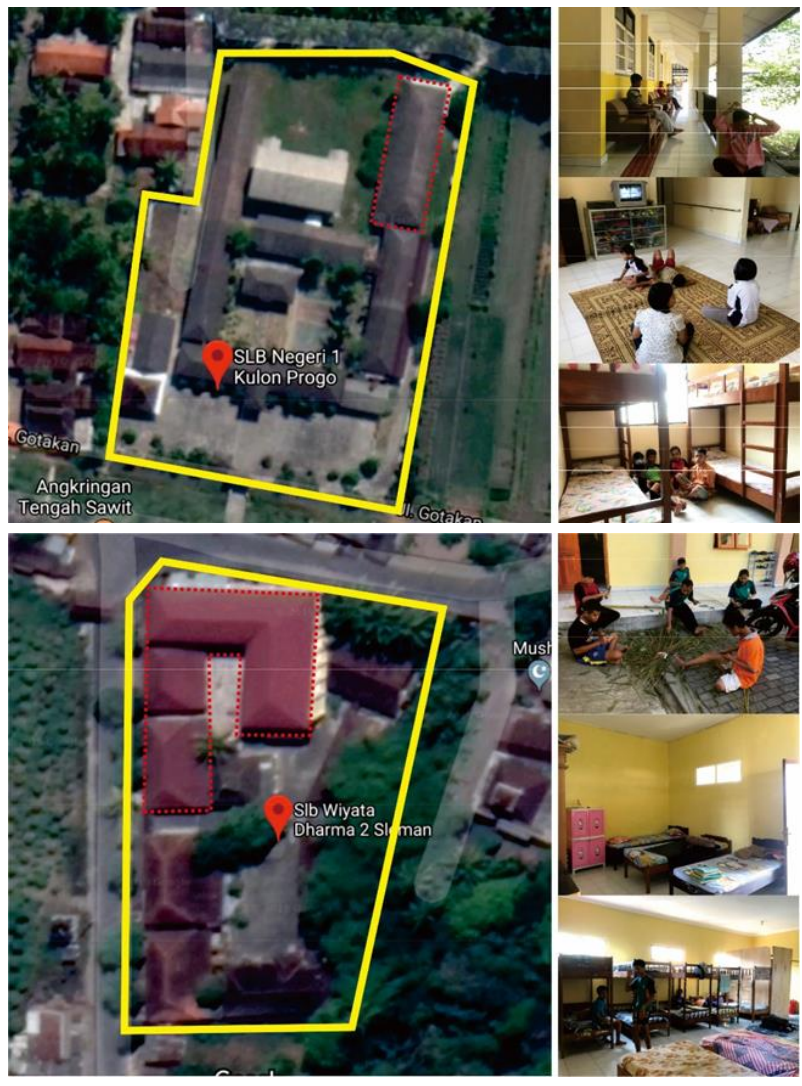


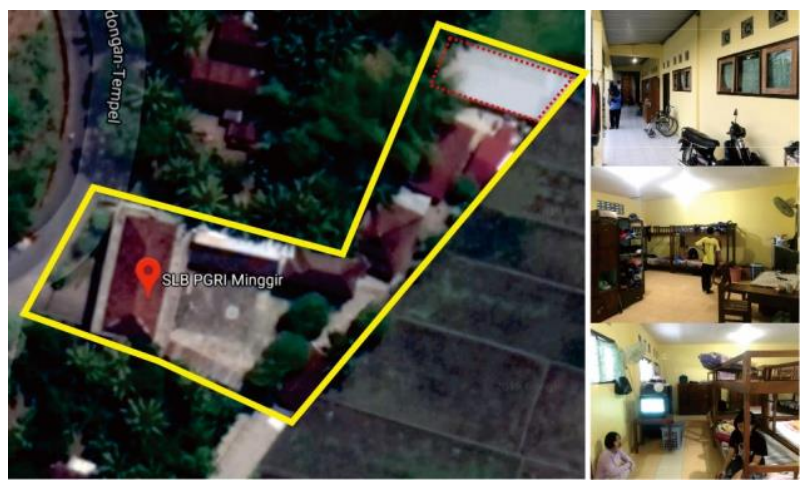

Gambar 1. Lokasi Amatan (atas - bawah): SLB Negeri 1 Kulon Progo; SLB C Wiyata Dharma 2; SLB PGRI Minggir (Penulis, 2020)

\section{Kualitas Lingkungan}

Sebelum masuk ke dalam tahap desain, perlu dilakukan evaluasi terhadap isu dan kebutuhan preferensi yang harus didiskusikan, diklarifikasi, dan dibuat lebih bermanfaat (Rapoport, 2005). Karena pada dasarnya sebuah "environmental quality" atau "better environment" adalah tujuan utama yang ingin dicapai dari sebuah desain.

Rapoport (1988) dalam Vischer \& Wifi (2017) mengatakan bahwa kualitas dari lingkungan buatan dapat dikategorikan ke dalam aspek instrumental, latent and symbolic meaning yang dapat dijelaskan sebagai berikut:

a. Instrumental merupakan aspek properti fisik dan kualitas properti fungsional untuk memudahkan seseorang melakukan tugasnya.

b. Latent merupakan aspek kualitas psikologis, sosial-budaya dan sosial-psikologis, meliputi: privasi, teritorialitas, personalisasi, dan lainnya.

c. Symbolic level merupakan aspek makna dan nilai-nilai dari elemen spasial dalam hal kebanggan, budaya, tradisi, dan lainnya.

Dalam hubungan manusia dan lingkungan tidak hanya dilihat dari kondisi lingkungan fisik, tetapi persepsi pengguna merupakan faktor penting yang harus diperhatikan.

Mendefinisikan environmental quality adalah tingkat kenyamanan yang diperoleh oleh penghuni pada suatu lingkungan tertentu. Merujuk pada functional comfort and environmental quality (workspace comfort pyramid) yang digambarkan melalui Habitability Threshold oleh Vischer \& Wifi (2017) dapat diuraikan sebagai berikut:

a. Physical comfort, merupakan standar minimum untuk kelayak hunian, seperti keamananan dan kesehatan. b. Functional comfort, merupakan kenyamanan yang dirancang secara fungsional untuk mendukung tugas seseorang, seperti kenyamanan termal dan tingkat kebisingan.

c. Psychological comfort, merupakan kondisi lingkungan sekitar yang dipersepsikan oleh pengguna, terkait dengan pengaruh laten dan makna simbolik dari EQ, antara lain teritori, privasi, dan personalisasi.

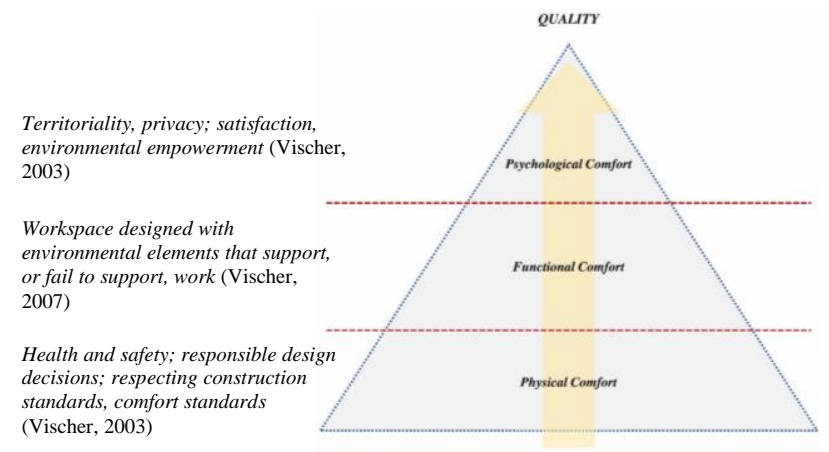

Gambar 2. Habitability Threshold (Vischer, 1989 dalam Vischer \& Wifi, 2017)

Pada dasarnya, persepsi mengenai kualitas lingkungan berkaitan dengan keseluruhan proses environmental learning (Haryadi \& Setiawan, 2014). Dalam kajian arsitektur lingkungan dan perilaku, kualitas lingkungan dapat dipahami secara subjektif (karena berhubungan dengan preferensi ideal seseorang atau sekelompok orang) yang dikaitkan dengan aspek psikologis dan sosio kultural penghuninya. Konsep ini sangat penting untuk mencapai kualitas lingkungan secara optimal.

Sekolah asrama memiliki kelebihan dan kekurangan dalam proses pengalaman hidup anak terhadap pengembangan kepribadiannya (Laiser \& Makewa, 2016). Selain itu, pendidikan dengan sistem sekolah asrama diharapkan mampu untuk mendidik secara intelektual, meningkatkan keterampilan, pengembangan budi pekerti, dan memelihara nilai-nilai moral peserta didik, sehingga mereka akan memiliki personalitas yang lebih utuh dan khas (Na'imah, Dwiyanti, \& Sriyanto, 2019), dimana kemandirian dan kecerdasan emosional tersebut bersama-sama berperan sebesar $61,3 \%$ terhadap penyesuaian diri pada siswa di asrama (N. K. Wulandari \& Rustika, 2016).

Merujuk pendapat Atmodiwirjo (2017), bahwa menentukan kualitas ruang bukan sebatas mendefinisikan properti dan spesifikasi dari elemen ruang, tetapi yang lebih penting adalah bagaimana susunan elemen tersebut mampu membangun sistem yang mendukung interaksi yang bermakna antara tubuh dan ruang, meliputi kesehatan, keamanan, dan keselamatan. 


\section{Kualitas Ruang di Asrama SLB}

Secara umum kualitas lingkungan memiliki peranan penting terhadap tercapainya kualitas hidup seseorang di dalam setting fisik tertentu. Hal ini merujuk, bahwa kualitas pada ruang-ruang yang tersedia akan dapat memberikan kontribusi penting bagi kebutuhan akomodasi yang mempengaruhi kesehatan mental dan fisik individu, dimana aspek tersebut berkaitan dengan lokasi, bentuk arsitektur, ukuran, dan kemudahan penggunaan (Işık, 1970; Peck \& Stewart, 1985; Seed \& Lloyd, 1997 dalam Yildirim \& Uzun, 2010).

Pada penelitian ini, kajian kualitas lingkungan dilakukan di asrama SLB yang memiliki perbedaan setting fisik. Hal tersebut bertujuan untuk mendapatkan gambaran ideal terkait penilaian kualitas lingkungan yang diberikan oleh penghuninya dalam hal ini ATG. Persepsi dan penilaian penghuni menjadi penting, hal ini merujuk pada pendapat Haryadi \& Setiawan (2014) bahwa kualitas lingkungan berkaitan dengan keseluruhan proses environmental learning. Dalam pelaksanaannya, penilaian kualitas lingkungan yang digunakan mengacu pada konsep Habitability Threshold oleh Vischer \& Wifi (2017), meliputi physical comfort, functional comfort, dan psychological comfort. Masingmasing variabel tersebut selanjutnya diimplementasikan pada ruang-ruang terukur, meliputi ruang privat (kamar tidur), semipublik (ruang tengah/ruang televisi), dan publik (teras).

Berdasarkan persepsi dan penilaian yang sudah diberikan oleh ATG melalui kuesioner, berikut gambaran umum terkait data kualitas lingkungan asrama SLB di tiga lokasi berbeda:

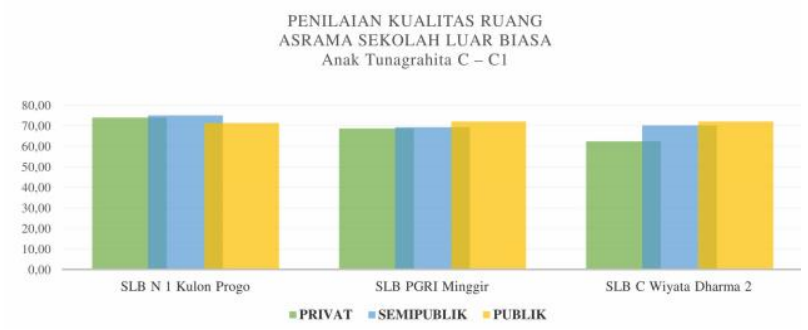

Gambar 3. Penilaian Kualitas Ruang Asrama SLB (Penulis, 2020)

Kriteria penilaian

- $\quad 00,00 \%$ s.d. $25,0 \%$ : Sangat Tidak Setuju

- $25,01 \%$ s.d. $50,00 \%$ : Tidak Setuju

- $50,01 \%$ s.d. $75,00 \%$ : Setuju

- $>75,00 \% \quad$ : Sangat Setuju

Sebagai catatan, bahwa acuan kritera tersebut merupakan persepsi dan penilaian anak tunagrahita terhadap tingkat kepuasan yang diperoleh dari masingmasing kualitas ruang terukur.
Pada gambar 3 secara umum menunjukkan, bahwa kualitas lingkungan di ketiga asrama SLB tergolong baik, artinya ATG merasa puas dengan kualitas ruang yang ada. Hal ini ditunjukkan dengan rata-rata penilaian yang diberikan ATG di masingmasing asrama SLB mencapai 70\%, walaupun dengan prosentase yang berbeda-beda di setiap variabelnya.

ATG memberikan penilaian sebesar $73,96 \%$ dan $71,41 \%$ pada ruang privat dan publik di asrama SLB Negeri 1 Kulon Progo, yang berarti mereka setuju terhadap kualitas baik yang diperoleh di dalam ruang tersebut. Bahkan untuk ruang tengah, penilaian ATG mencapai $75,12 \%$ yang berarti sangat setuju. Penilaian ATG pada ruang privat dan semipublik di asrama SLB PGRI Minggir tidak setinggi pada lokasi sebelumnya, hanya sebesar $68,75 \%$ dan $69,32 \%$. Walaupun demikian ruang-ruang tersebut masih dianggap memiliki kualitas ruang yang baik. Sementara, untuk ruang publik, sedikit memiliki nilai lebih tinggi, yaitu 72,16\%.

Asrama SLB C Wiyata Dharma 2 dengan kelengkapan fasilitas yang dimilikinya, ternyata ATG hanya memberikan penilaiannya terhadap ruang privat sebesar $62,50 \%$ dan $70,21 \%$ pada ruang semipublik. Penilaian untuk ruang publik sebesar $72,08 \%$ diberikan oleh ATG. Walaupun demikian, ketiga ruang tersebut masih dianggap mampu memberikan kualitas yang baik untuk mendukung aktivitas harian ATG. Hasil temuan pada kondisi ruang privat di SLB C Wiyata Dharma 2 menunjukkan, bahwa tatanan fisik dan kapasitas ATG di dalam kamar berpengaruh terhadap kualitas kebutuhan privasi penghuni. Semakin banyak jumlah ATG berada di dalam satu unit kamar, semakin besar kemungkinan intrusi tersebut akan berdampak pada penghuni lainnya, seperti gangguan suara atau jenis aktivitas lain yang dilakukan di dalam kamar.

Persepsi dan penilaian positif ATG terhadap kualitas ruang di ketiga asrama SLB tersebut di atas, tentunya masih harus mendapatkan perhatian di beberapa variabelnya. Aspek psycology comfort (gangguan suara) dan functional comfort (suhu udara) merupakan permasalahan yang ditemukan di tiga asrama SLB pada ruang privat, semipublik, dan publik. Sementara di SLB PGRI Minggir, dimensi ruang menjadi variabel yang memiliki nilai rendah pada ketiga ruang tersebut.

Aspek ketiga, physical comfort memiliki bobot penilaian yang tinggi di ketiga asrama SLB. ATG telah menyampaikan persepsi dan penilaiannya bahwa asrama SLB tersebut memberikan rasa aman selama tinggal di dalamnya. Temuan ini dianggap positif karena sesuai dengan konsep asrama yang disampaikan oleh Kocaman et al., (2017), bahwa akomodasi asrama merupakan salah satu kebutuhan paling penting untuk menyediakan dan mempertahankan perasaan aman. Selain itu, poin ini telah memenuhi salah satu syarat yang harus 
diperhatikan terkait kebutuhan ruang ATG, antara lain keamanan dan keselamatan (Mendiknas, 2008; PKLK, 2014).

Berdasarkan beberapa temuan di atas, aspek kualitas lingkungan yang menjadi perhatian pada ketiga asrama SLB tersebut adalah:

a. Ruang privat, voice control (gangguan suara) dan temperature (suhu udara). Aspek tersebut memiliki implikasi terhadap kapasitas dan daya tampung kamar tidur, tatanan pengisi ruang (perabot), beserta rasio bukaannya.

b. Ruang semipublik, temperature dan noise distraction (kebisingan). Aspek tersebut memiliki implikasi terhadap rasio bukaan dan posisi ruang.

c. Ruang publik, voice control dan temperature. Aspek tersebut memiliki implikasi terhadap posisi dan orientasi ruang.

Merujuk pada beberapa poin tersebut di atas, dominasi gangguan suara dan suhu udara merupakan dua hal yang menjadi perhatian lebih dalam perancangan asrama SLB bagi anak tunagrahita. Sementara kasus dimension (luas ruangan) hanya ditemukan di asrama SLB PGRI Minggir. Kondisi ini memang sesuai, apabila merujuk pada pemanfaatan ruang sebesar $75 \%$ aktivitas harian yang dilakukan ATG di dalam kamar dengan tingkat adaptasi spasial yang cukup tinggi juga. Artinya bahwa densitas menjadi isu penting di asrama SLB PGRI Minggir. Pada kasus asrama SLB C Wiyata Dharma 2, kelengkapan infrastruktur nyatanya tidak selalu berbanding lurus dengan persepsi dan penilaian yang diberikan.

Melihat hasil temuan di tiga lokasi studi yang beragam, dapat dikatakan bahwa kuantitas bukan menjadi faktor utama dalam memberikan kenyamanan secara fisik, fungsional, dan psikologi ATG. Lebih dari itu, kualitas lingkungan atau ruang di dalamnya yang menentukan apakah ketiga variabel tersebut, yaitu physical comfort, functional comfort, dan psychological comfort dapat dicapai dengan baik.

\section{Keterkaitan Kualitas Ruang dengan Adaptasi Spasial}

Perbedaan prosentase kualitas ruang yang diberikan ATG di ketiga asrama SLB menunjukkan bagaimana setting fisik berpengaruh terhadap persepsi dan kepuasaan anak-anak dalam memanfaatkan areaarea tersebut. Studi yang dilakukan menunjukkan, bahwa penilaian penghuni terhadap kualitas ruang berbanding lurus dengan pemanfaatan ruangnya. Hal tersebut dapat dilihat dari data berikut yang diperoleh berdasarkan pemetaan perilaku selama penelitian di lakukan di tiga lokasi asrama SLB:
Tabel 2. Pemanfaatan Ruang (Penulis, 2020)

\begin{tabular}{llrrrrrr}
\hline \multicolumn{2}{c}{$\begin{array}{c}\text { Pemanfaatan Ruang } \\
\text { Weekdays - Weekend }\end{array}$} & \multicolumn{2}{c}{$\begin{array}{c}\text { SLB Negeri 1 } \\
\text { KP }\end{array}$} & \multicolumn{2}{c}{$\begin{array}{c}\text { SLB PGRI } \\
\text { MG }\end{array}$} & \multicolumn{2}{c}{$\begin{array}{c}\text { SLB C } \\
\text { WD 2 }\end{array}$} \\
\hline PRIVAT & Kamar tidur & 39 & $24,68 \%$ & 115 & $75,66 \%$ & 66 & $40,74 \%$ \\
\hline \multirow{5}{*}{ SEMIPUBLIK } & Dapur & 21 & $13,29 \%$ & - & $0,00 \%$ & - & $0,00 \%$ \\
\cline { 2 - 8 } & Lorong & 33 & $20,89 \%$ & - & $0,00 \%$ & - & $0,00 \%$ \\
\cline { 2 - 8 } & Ruang makan & - & $0,00 \%$ & - & $0,00 \%$ & 21 & $12,96 \%$ \\
\cline { 2 - 8 } & Ruang televisi & - & $0,00 \%$ & - & $0,00 \%$ & 46 & $28,40 \%$ \\
\hline \multirow{3}{*}{ PUBLIK } & Ruang tengah & 40 & $25,32 \%$ & - & $0,00 \%$ & 1 & $0,62 \%$ \\
\hline & Emperan dapur & 7 & $4,43 \%$ & - & $0,00 \%$ & - & $0,00 \%$ \\
\hline & Teras & 18 & $11,39 \%$ & 36 & $23,68 \%$ & 25 & $15,43 \%$ \\
\hline & Ruang lainnya & - & $0,00 \%$ & 1 & $0,66 \%$ & 3 & $1,85 \%$ \\
\hline & Total & 158 & $100 \%$ & 152 & $100 \%$ & 162 & $100 \%$ \\
\hline
\end{tabular}

Merujuk pada gambar 3 dan pembahasan sebelumnya, dapat dilihat bahwa temuan tersebut berkaitan dengan data pada tabel 2, dimana antara persepsi dan penilaian kualitas ruang yang diberikan ATG berbanding lurus dengan tingkat pemanfaatannya.

Berdasarkan pemanfaatan pada ruang-ruang terukur, selanjutnya akan dikaji kembali adaptasi spasialnya. Hal ini dilakukan untuk mengetahui perbandingan antara pemanfaatan dan adaptasi spasial yang dilakukan ATG di dalamnya, kaitannya untuk melihat hubungan antara kualitas ruang terhadap adaptasi spasial di dalam asrama SLB. Berikut merupakan nilai perbandingan antara pemanfaatan dan adaptasi spasial yang dilakukan ATG di dalam ruang privat, semipubik, dan publik.

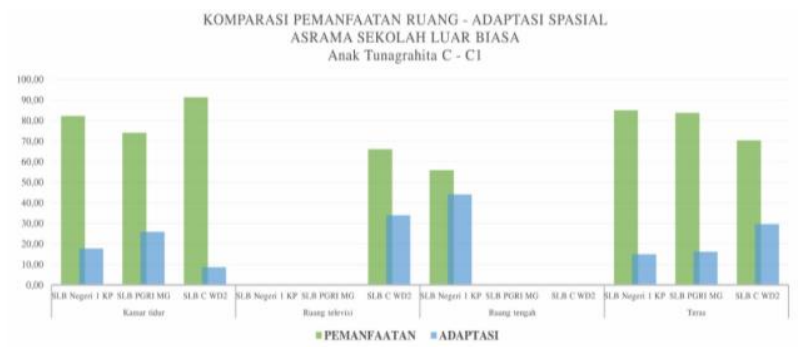

Gambar 4. Komparasi Pemanfaatan Ruang - Adaptasi Spasial Asrama SLB (Penulis, 2020)

Gambar 4 menunjukkan prosentase pemanfaatan ruang yang lebih tinggi daripada adaptasi spasial yang dilakukan ATG di dalam masing-masing ruang terukur. Prosentase pemanfaatan ruang privat di ketiga asrama SLB sebesar $74,11 \%$ s.d. $91,30 \%$, sementara adaptasi spasial yang dilakukan hanya sebesar $8,70 \%$ s.d. $25,89 \%$. Ruang semipublik dimanfaatkan oleh ATG sebesar $55,88 \%$ s.d. $66,07 \%$ dengan adaptasi spasial $33,92 \%$ s.d. $44,12 \%$. Adaptasi spasial yang terjadi di dalam ruang semipublik terbilang cukup tinggi, mengingat fungsinya sebagai ruang bersama (shared spaces) yang mengakomodasi banyak aktivitas harian, baik dilakukan pada waktu yang sama ataupun berbeda. Kondisi tersebut menuntut ATG untuk seringkali menyesuaian ruang terhadap kebutuhan aktivitas yang sedang dilakukannya. Sementara, pemanfaatan ruang publik sebesar $70,37 \%$ s.d. $85,00 \%$ dengan angka adaptasi spasial $15,00 \%$ s.d. $29,63 \%$. 
Kondisi di atas menunjukkan, bahwa tingkat adaptasi spasial yang rendah di dalam suatu ruang, mengindikasikan kualitas ruang yang dimiliki asrama SLB dapat dikatakan baik. Temuan ini sesuai dengan pendapat yang disampaikan oleh Rapoport (2005), semakin tinggi tingkat kesesuaian lingkungan dan preferensi, semakin rendah upaya adaptasi yang dilakukan di dalamnya.

Hal yang menjadi perhatian pada studi ini adalah adaptasi spasial di dalam ruang privat (kamar tidur) asrama SLB PGRI Minggir yang terbilang cukup tinggi. Kondisi tersebut dikarenakan keterbatasan fasilitas yang menuntut berbagai aktivitas harian dilakukan di dalam ruang yang sama. Berbeda dengan dua asrama SLB lainnya yang relatif memiliki fasilitas beragam untuk masing-masing jenis aktivitas harian ATG. Sekalipun demikian, adaptasi spasial yang dilakukan di dalam ruang-ruang tersebut lebih bersifat behavioral tanpa ada reaksi untuk mengubah setting fisik secara berlebihan.

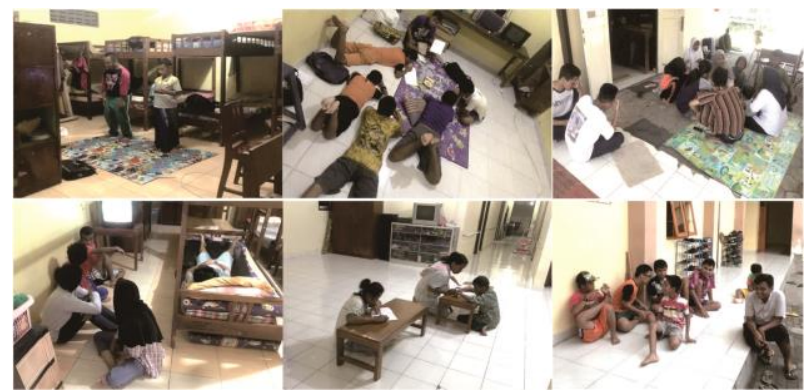

Gambar 5. Pemanfaatan Ruang - Adaptasi Spasial ATG di dalam Ruang Privat, Semipublik, dan Publik (Penulis, 2020)

Selain itu, gambar 4 juga menunjukkan adanya kecenderungan yang sama antara perbandingan pemanfaatan dan adaptasi spasial yang ditemukan di ruang tengah asrama SLB Negeri 1 Kulon Progo dan ruang televisi asrama SLB C Wiyata Dharma 2. Keduanya memiliki perbandingan prosentase yang hampir sama. Berdasarkan pengamatan perilaku, aktivitas harian ATG banyak dilakukan di ruang yang bersifat semipublik dan memiliki dimensi yang lebih luas. Hal ini merujuk pada peluang ATG untuk memperoleh ruang gerak yang lebih leluasa. Ruang tersebut umumnya bersifat fleksibel untuk dimanfaatkan berbagai ragam kegiatan harian di dalam asrama, seperti ruang tengah dan ruang televisi.

Kedua kondisi tersebut di atas selaras dengan pendapat High \& Sundstrom (1977) dalam Wulandari (2016), bahwa ruang yang fleksibel memudahkan penghuni untuk melakukan adaptasi ruang sesuai kebutuhan aktivitas yang dilakukannya, sementara ruang yang tidak fleksibel akan menghambat proses adaptasi.
Terlepas dari fungsi utama asrama SLB sebagai akomodasi siswa, sesuai dengan hasil yang ditunjukkan pada persepsi dan penilaian kualitas ruang, nyatanya ruang-ruang semipublik dan publik berkontribusi terhadap pencapaian kualitas hidup ATG selama berada di asrama. Merujuk kembali pada konsep asrama SLB yang hadir untuk memberikan kemudahkan layanan dan membangun sosialisasi di antara anak-anak berkebutuhan khusus (PSMA, 2018), hal ini menjadi penting untuk diperhatikan, bahwa ruang-ruang semi terbuka atau terbuka memberikan peranan vital dalam mendukung pemenuhan kebutuhan ideal ATG dalam melakukan aktivitas hariannya.

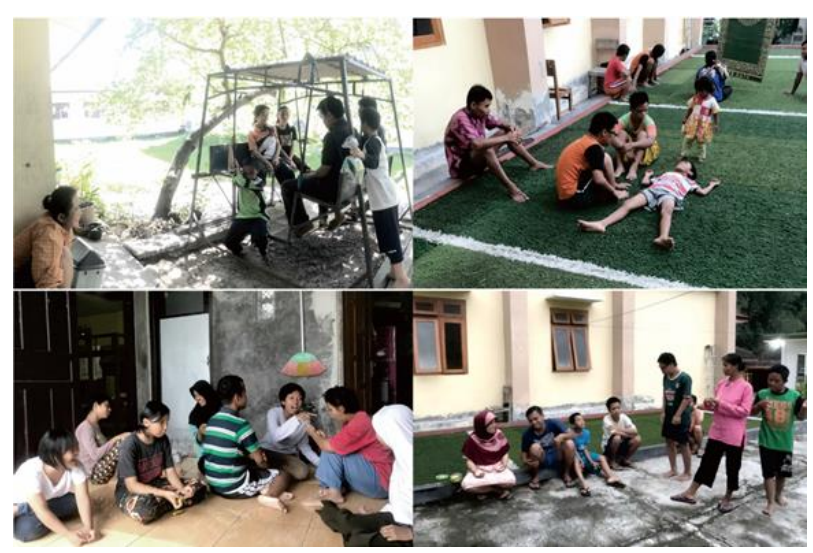

Gambar 6. Open Space sebagai Ruang Sosialisasi ATG (Penulis, 2020)

Merujuk pada hasil studi yang dilakukan oleh Mozaffar dan Mirmoradi (2012), bahwa ruang luar yang luas dan terbuka memungkinkan anak-anak untuk bergerak lebih bebas daripada di dalam gedung. Selain itu, merujuk beberapa pendapat di dalam penelitian yang sama lansekap atau ruang hijau juga dapat mendorong perubahan positif dalam perilaku bermain siswa beserta perilaku sosialnya (Taylor, Wiley, Kua \& Sullivan, 1998; Cheskey, 2001; Wells \& Evans, 2003).

\section{Kesimpulan}

Berdasaran studi yang dilakukan di tiga asrama SLB dengan setting fisik berbeda, menunjukkan bahwa persepsi dan penilaian penghuni (ATG) terhadap kualitas ruang-ruang terukur berbanding lurus dengan pemanfaatan ruangnya. Selain itu, merujuk pada variabel penilaiannya, ketiga asrama SLB dapat dikatakan memiliki kualitas yang baik, walaupun dengan besaran angka penilaian yang beragam.

Dalam hal keterkaitan antara kualitas ruang dengan adaptasi spasial, terlihat dari angka pemanfaatan ruang (kamar tidur, ruang tengah/ruang televisi, teras) yang lebih tinggi daripada adaptasi spasial yang dilakukan ATG di dalamnya. Temuan ini mengindikasikan bahwa ruang-ruang terukur tersebut masih dianggap mampu untuk mendukung aktivitas 
harian ATG dengan tingkat penyesuaian yang rendah. Walaupun, adaptasi spasial di dalam ruang privat asrama SLB PGRI Minggir terbilang cukup tinggi hampir sebanding dengan pemanfaatan ruangnya, hal ini dikarenakan keterbatasan fasilitas yang menuntut berbagai aktivitas harian dilakukan di dalam ruang yang sama. Berbeda dengan dua asrama SLB lainnya yang relatif memiliki fasilitas beragam untuk masing-masing jenis aktivitas harian ATG, sehingga usaha untuk melakukan penyesuaian terbilang cukup rendah. Sekalipun demikian, adaptasi spasial yang dilakukan di dalam ruang-ruang tersebut lebih bersifat behavioral tanpa ada reaksi untuk mengubah setting fisik secara berlebihan.

Selain itu, ketersediaan ruang terbuka menjadi penting bagi keberlangsungan aktivitas harian dan kehidupan sosial ATG selama berada di dalam asrama SLB. Temuan tersebut bisa digunakan sebagai salah satu poin penting, bahwa perencanaan asrama SLB (dalam hal ini untuk anak tunagrahita) tidak hanya berfokus pada bagaimana bisa memberikan fasilitas akomodasi, lebih dari itu aspek psychology, functional, dan physical comfort penghuni dapat dipenuhi dengan baik.

Pada akhirnya, penelitian ini masih memberikan peluang yang sangat lebar untuk dilakukan pada lokasi studi dengan lingkup ketunaan yang beragam lainnya, yaitu tunanetra, tunarungu, tunadaksa, tunalaras, autis, dan tunaganda. Bahkan, penelitian sejenis dapat diimplementasikan pada asrama sekolah reguler, pesantren, dan inklusi.

\section{Daftar Pustaka}

Atmodiwirjo, P. (2017). Interioritas Dalam Arsitektur Untuk Mendukung Peningkatan Kualitas Hidup. Depok: Fakultas Teknik Universitas Indonesia.

Chiara, J. De, \& Callender, J. (1983). Timesaver Standards For Building Types (2nd ed.). New York: McGraw-Hill Book.

Desiningrum, D. R. (2016). Psikologi Anak Berkebutuhan Khusus. Yogyakarta: Psikosain.

Hadi, S. (1991). Analisis Butir untuk Instrumen Angket, Tes, dan Skala Nilai. Yogyakarta: Andi Offset.

Haryadi, \& Setiawan, B. (2014). Arsitektur, Lingkungan dan Perilaku. Yogyakarta: Gadjah Mada University Press.

Kocaman, G. Y., Sezer, F. S., \& Cetinkol, T. (2017). User Satisfaction of Indoor Environmental Quality in Student Dormitories. European Journal of Sustainable Development, 6(1), 11-12. https://doi.org/10.14207/ejsd.2017.v6n1p11

Laiser, S., \& Makewa, L. N. (2016). The influence of Boarding School to Young Children: A Case of Two Boarding Schools in Hai District in Kilimanjaro, Tanzania. International Jounal of Education and Research, 4(6), 73-84.
Mendiknas. Peraturan Menteri Pendidikan Nasional Republik Indonesia Tentang Standar Sarana dan Prasarana untuk SDLB, SMPLB. dan SMALB, Pub. L. No. 33 (2008). Indonesia.

Menhumkam. Undang-Undang Republik Indonesia Tentang Penyandang Disabilitas, Pub. L. No. 8, Kementerian Hukum dan Hak Asasi Manusia Republik Indonesia (2016). Jakarta, Indonesia.

Mozaffar, F., \& Mirmoradi, S. S. (2012). Effective Use of Nature in Educational Spaces Design. Organization, Technology and Management in Construction An International Journal, 4(1), 381392. https://doi.org/10.5592/otmcj.2012.1.3

Na'imah, T., Dwiyanti, R., \& Sriyanto, S. (2019). Grounded Theory Approach to Assess the Process of Students ' Well- Being Achievement in Islamic Boarding School. IJPE, XI(1), 31-39.

PKLK, D. P. (2014). Standar Bangunan Sekolah Luar Biasa/Sekolah Khusus Untuk Peserta Didik Tunagrahita Tingkat Pendidikan Dasar. Jakarta: Kementerian Pendidikan dan Kebudayaan.

PSMA, D. (2018). Sekolah Menengah Atas Berasrama. (D. P. SMA, Ed.). Jakarta: Kemdikbud.

Rapoport, A. (2005). Culture, Architecture, and Design. Chicago: Locke Science Publishing Company, Inc.

Sommer, R., \& Sommer, B. B. (1980). A Practical Guide to Behavioral Research (Tool and Techniques). Oxford: Oxford University Press, Inc.

Vischer, J. C., \& Wifi, M. (2017). The Effect of Workplace Design on Quality of Life at Work. Handbook of Environmental Psycology and Quality of Life Reserach. https://doi.org/10.1007/978-3-319-31416-7

Wardani, I. G. A. K., Tarsidi, D., Hernawati, T., \& Astati. (2007). Pengantar Pendidikan Luar Biasa. Jakarta: Universitas Terbuka.

Wulandari, N. K., \& Rustika, I. M. (2016). Peran Kemandirian dan Kecerdasan Emosional Terhadap Penyesuaian Diri Pada Siswa Asrama Tahun Pertama SMK Kesehatan Bali Medika Denpasar. Jurnal Psikologi Udayana, 3(2), 232-243.

Wulandari, R. (2016). Analisa Kaitan Desain Asrama Dengan Perilaku Penghuni Melalui Studi Analisa Konten Penelitian Sejenis. IDEALOG, Jurnal Desain Interior \& Desain Produk, 1(3), 219-231.

Yildirim, K., \& Uzun, O. (2010). The Effects of Space Quality of Dormitory Rooms on Functional and Perceptual Performance of Users: Zübeyde Hanim Sorority. Gazi University Journal of Science, 23(4), 519-530.

Yusuf, M. A., Hayati, A., \& Faqih, M. (2018a). Concept of Female Dormitory Bedrooms Based on Students' Preference and Adaptation, Case Study: 
Type B Non-Affiliated Organization Pesantren. Architecture \& Environment, 17(2), 169-194.

Yusuf, M. A., Hayati, A., \& Faqih, M. (2018b). Design Parameters of Pesantren's Dormitory Based on Student's Preference and Adaptation. EMARA:

Indonesian Journal of Architecture, 4(2), 85-95. 